\title{
POLA KOMUNIKASI ETNIS ARAB DAN ETNIS SUNDA DALAM PERKAWINAN MUT'AH DI KECAMATAN PACET KABUPATEN CIANJUR
}

\author{
Yessi Sri Utami* \\ Fakultas Ilmu Komunikasi Universitas Putra Indonesia (UNPI) Cianjur
}

\begin{abstract}
ABSTRAK
Penelitian ini menggunakan pendekatan kualitatif dengan metode etnografi komunikasi. Subjek penelitian ini adalah Laki-laki Etnis Arab, Perempuan Etnis Sunda, guide, sopir, khadamah, kepala Desa dan ketua MUI Desa Sukanagalih yang ditentukan secara purposive sampling. Fokus penelitian ini adalah mengkaji Pola Komunikasi Etnis Arab dan Etnis Sunda dalam Perkawinan Mut'ah di Kecamatan Pacet Kabupaten Cianjur. Teori yang digunakan dalam penelitian ini adalah teori interaksi simbolik dan teori pelanggaran harapan. Hasil Penelitian mengungkapkan bahwa aktivitas komunikasi Etnis Arab dan Etnis Sunda dalam Perkawinan Mut'ah di Kecamatan Pacet Kabupaten Cianjur dibangun dari situasi komunikatif, peristiwa komunikatif dan tindak komunikatif. Komponen yang dominan membentuk peristiwa komunikasi dalam perkawinan mut'ah adalah setting, bentuk dan isi pesan, norma, interpretasi norma, kebiasaan, dan genre. Hubungan antarkomponen yang membentuk pola komunikasi dalam perkawinan mut'ah antara lain: 1) Hubungan lokasi (tempat) dan waktu dengan bentuk pesan; 2) Hubungan genre dengan partisipan; 3) Hubungan Norma dengan Kebiasaan; 4) Hubungan Kebiasaan dengan interpretasi nilai. Hubungan antarkomponen tersebut membentuk pola komunikasi, antara lain: 1) Pola Komunikasi Calon Suami mut'ah dengan Perantara (Biong) dan Calon Istri mut'ah dengan Perantara (Biong) Ketika Dawwir, Pola komunkasi Calon Suami mut'ah dengan Perantara (Biong) dan Calon Istri mut'ah dengan Perantara (Biong) ketika ittifaq. 2) Pola Komunikasi Suami Istri Mut'ah. 3) Pola Komunikasi Suami Istri mut'ah dengan keluarga istri atau keluarga suami. 4) Pola komunikasi suami istri mut'ah dengan masyarakat sekitar.
\end{abstract}

Kata-kata Kunci: Etnografi Komunikasi, Etnis Arab, Etnis Sunda, Pola Komunikasi, Interaksi simbolik, Pelanggaran harapan

\section{COMMUNICATION PATTERN OF ARABIAN ETHNIC AND SUNDANEESE ETHNIC ON MUT'AH MARRIAGE IN PACET, CIANJUR}

\begin{abstract}
This research using qualitatif approach with etnografy communication methode. The subject of the thesis are etnic arabian men, etnic sundaneese women, guide, driver, khadamah, village elder, and the chairman of MUI of Sukanagalih Village whom decided by a purpose sampling. The focus of the thesis is to analyze The Communication Pattern of Arabian Ethnic and Sundaneese Ethnic on Mut'ah Marriage in Kecamatan Pacet, Kabupaten Cianjur. The theory which used in the thesis are simbolic interaction theory and violance expectation theory. The thesis reveals that the activity of etnic arabian communication and etnic sundaneese on mut'ah marriage in Kecamatan Pacet Kabupaten Cianjur among the strings formed a communication pattern, which are: 1) the mut'ah bridegroom communication pattern with the mediator (Biong) and mut'ah bride with the mediator when Dawwir, mut'ah bridegroom communication pattern with the mediator and the mut'ah bride with mediator when ittifaq. 2) the mut'ah bride and groom communication pattern. 3) The mut'ah bride and groom communication pattern with the bride"s family or bridegroom "s family. 4) The mut'ah bride and groom communication pattern with the neighbourhood around. After explaining the relationship among the strings, then found a communication pattern, which are: 1) the mut'ah bridegroom communication pattern with the mediator (Biong) and mut'ah bride with the mediator when Dawwir, mut'ah bridegroom communication pattern with the mediator and the mut'ah bride with mediator when ittifaq. 2) the mut'ah bride and groom communication pattern. 3) The mut'ah bride and groom communication pattern with the bride"s family or bridegroom"s family. 4) The mut'ah bride and groom communication pattern with the neighbourhood around.
\end{abstract}

Keywords: Ethnography Communication, Arabian Etnic, sundaneese Etnic, communication pattern, Simbolic Interaction, violance expectation.

\footnotetext{
* Korespondensi: Yessi Sri Utami, S.Sos.,M.I.Kom. Fakultas Ilmu Komunikasi Universitas Putra Indonesia(UNPI) Cianjur. Jl. Dr. Muwardi no.66 By Pass Cianjur 43215. Email: yessikhansa@gmail.com
} 


\section{PENDAHULUAN}

Perilaku Kawin Mut'ah di kawasan Cipanas Cianjur tidak terlepas dari keberadaan kawasan ini sebagai tempat wisata khususnya bagi orang etnis Arab. Wisatawan Etnis Arab umumnya laki-laki dari negeri-negeri Arab, seperti Arab Saudi, Kuwait, Irak, juga dari Turki. Interaksi yang dinamis dan intens antara wisatawan etnis Arab dengan Penduduk setempat menimbulkan kedekatan diantara keduanya. Bagi warga setempat, laki-laki beretnis Arab disebut dengan "Onta”. Para Onta berinteraksi dengan warga setempat untuk keperluan mendapatkan sopir yang biasanya merangkap pemandu jalan atau pemandu wisata (guide), menjadi pembantu rumah tangga (hadammah), pencari atau penjaga villa dan petugas salon. Vila tempat tinggal orang Arab terisi hingga 400 vila pada "musim Arab" yakni pada bulan liburan akhir tahun, antara Mei dan Juni serta pada waktu setelah musim haji (Idul Adha). Keberadaan para wisatawan maupun imigran beretnis Arab memunculkan suasana yang berbeda dengan kawasan lainnya di Kabupaten Cianjur.

Para "Onta" juga berinteraksi secara khusus dengan perempuan setempat. Hubungan yang lebih intim yang terjadi antara perempuan etnis sunda dengan laki-laki etnis Arab kemudian mencuatkan perilaku adanya nikah mut'ah atau kawin kontrak atau masyarakat setempat menyebutnya zuwaj muaggot. Kawin mut'ah yaitu kawin sementara atau temporal dalam jangka waktu tertentu. Kawin Mut'ah adalah ikatan tali perkawinan antara seorang laki-laki dan perempuan dengan mahar yang telah disepakati, yang disebut dalam akad sampai pada batas waktu yang ditentukan, sesuai kesepakatan kedua belah pihak tanpa adanya paksaan dan tekanan apapun (Al Jawi, 2013).

Perilaku nikah temporal ini merebak biasanya hanya diketahui secara rahasia di daerah Cipanas dan diketahui khalayak yang lebih luas melalui media massa memberitakannya baik dalam media cetak maupun elektronik seperti yang ditemukan dalam kawin Mut'ah menurut warga setempat dilakukan dengan alasan menghindari zina yang diharamkan oleh agama Islam. Pada umumnya umur perkawinannya biasanya 5 (lima) hari sampai dengan dua bulan.

Para laki-laki-arab yang berwisata ke Cipanas kemudian berencana kawin mut'ah dengan perempuan setempat memiliki pola komunikasi yang khas. Para laki-laki Arab tidak mencari pasangannya sendiri, melainkan dikelilingi oleh berberapa pihak yang di sekitarnya, ada semacam calo/makelar atau mak comblang yang menghubungkan mereka dengan turis laki-laki dari Arab. Bahkan, beberapa keluarga perempuan setempatpun memiliki peran terjadinya kawin mut'ah ini. Oleh karena itu, fokus penelitian ini adalah mengkaji pola komunikasi etnis arab dan etnis sunda dalam perkawinan mut'ah di kecamatan Pacet kabupaten Cianjur (studi etnografi pola komunikasi etnis arab dan etnis sunda dalam perkawinan mut'ah di kecamatan Pacet kabupaten Cianjur).

\section{METODE PENELITIAN}

Penelitian ini menggunakan metode penelitian kualitatif dengan pendekatan studi etnografi komunikasi. Pengertian Penelitian kualitatif secara sederhana menurut Deddy Mulyana adalah penelitian yang bersifat interpertif (menggunakan penafsiran) yang melibatkan banyak metode dalam menelaah masalah penelitiannya. (Mulyana, 2008: 5). Penelitian ini menempatkan manusia sebagai makhluk yang dinamis dan mempertimbangkan kehidupan manusia yang selalu berubah.

Penelitian kualitatif relevan digunakan dengan pendekatan studi etnografi komunikasi dalam meneliti pola komunikasi etnis Arab dan Etnis Sunda dalam Kawin Mut'ah. Metode EtnografiKomunikasiberbeda dengan etnografi konvensional. Hal ini diungkapkan oleh Engkus Koeswarno dalam bukunya Etnografi Komunikasi: "Pada Etnografi Komunikasi, fokus perhatiannya adalah perilaku komunikasi dalam tema kebudayaan tertentu, jadi bukan keseluruhan perilaku seperti dalam etnografi. Perilaku komunikasi menurut ilmu komunikasi adalah tindakan atau kegiatan seseorang, kelompok atau khalayak, ketika terlibat dalam proses komunikasi." (Koeswarno, 2008: 35).

Etnografi komunikasi memulai penyelidikan dengan mengenali perilaku yang khas dan kemudian mengakhirinya dengan penjelasan pola-pola komunikasi dalam konteks 
sosiokultural. Hymes dalam Koeswarno (2008) mengemukakan tahapan untuk melakukan penelitian etnografi komu-nikasi dalam suatu masyarakat tutur yaitu (1) Identifikasi peristiwaperistiwa komunikasi yang terjadi secara berulang (recurrent event), (2) Inventarisasi komponen komunikasi yang membangun peristiwa komunikasi yang berulang tersebut dan (3) Temukan hubungan antarkomponen komunikasi yang membangun peristiwa komunikasi yang akan dikenal kemudian sebagai pemolaan komunikasi (communication patterning) (Koeswarno, 2008: 27).

Peristiwa komunikasi yang berulang (recurrent event) adalah peristiwa-peristiwa komunikasi yang signifikan dan menjadi ciri khas dari perilaku komunikasi suatu kelompok masyarakat. Komponen komunikasi menurut etnografi komunikasi adalah unit-unit komunikasi yang menunjang terjadinya satu peristiwa komunikasi. Dell Hymes mengungkapkan model yang berisi komponen komunikasi tersebut dengan diakronimkan dalam kata SPEAKING, yang terdiri dari: setting/scene, partisipants, ends, act sequence, keys, instrumentalities, norms of interaction, genre. Hubungan antarkomponen yang dimaksud adalah bagaimana setiap komponen komunikasi saling bekerja sama untuk menciptakan perilaku komunikasi yang khas dari kelompok tersebut. Hubungan antarkomponen inilah yang kemudian disebut pemolaan komunikasi (communication pattering).

Teknik penentuaninforman dalampenelitian etnografi dilakukan dengan menentukan gate keeper. Gatekeeper yaitu seseorang yang merupakan anggota atau seseorang yang diakui sebagai bagian dari masyarakat yang akan diteliti (Koeswarno, 2008: 62). Pemilihan informan kunci dilakukan dengan teknik purposive sampling. Purposive sampling termasuk satu dari beberapa jenis pengambilan sampel nonprobabilitas karena peneliti tidak bertujuan untuk menggeneralisasikan temuan penelitian (Mulyana, 2008: 187). Informan penelitian ini berjumlah 11 orang yang terlibat dalam perilaku kawin mut'ah antara Laki-laki beretnis Arab dan Perempuan beretnis Sunda di kawasan Cipanas Cianjur.
Teknik pengumpulan data utama yang digunakan dalam penelitian ini adalah: 1) metode introspeksi, karena salah satu kebudayaan yang diteli oleh Peneliti adalah kebudayaan sendiri yakni kebudayaan Sunda; 2) observasi partisipan Teknik mencuri dengar (eavesdropping), Teknik Melacak (tracer), dan Sentizing concepts, yaitu kepekaan perasaan yang ada dalam diri peneliti serta 3) wawancara mendalam. Selain itu juga digunakan metode Focus Group Discussion (FGD).

\section{HASIL DAN PEMBAHASAN}

Pola Komunikasi calon suami (etnis Arab) dengan perantara dan Calon Istri mut'ah (etnis Sunda) dengan perantara terjadi dalam peristiwa komunikasi dawwir (mencari). Proses dawwir (mencari) dalam perkawinan mut'ah di Cipanas Cianjur dimulai ketika seorang laki-laki etnis Arab mengutarakan niatnya untuk menikah mut'ah kepada perantara (Biong). Ketika seorang laki-laki mengutarakan niatnya untuk mencari perempuan untuk dinikahi mut'ah, maka dalam pikirannya ia mencoba membangun makna yang sama dengan perantara (Biong). Dalam interaksi simbolik Mead percaya bahwa manusia mengembangkan pikiran melalui interaksi dengan orang lain (Turner, 2012: 105).

Demikian pula penguasaan bahasa Arab oleh perantara (Biong) yang biasa berbahasa Sunda atau berbahasa Indonesia adalah cara perantara (Biong) untuk secara simbolis menempatkan dirinya sendiri dalam diri khayalan dari orang lain. Proses ini dinamakan pengambilan peran (role taking). Proses ketika perantara (Biong) menjelaskan kepada perempuan yang mau dinikahi $m u t$ 'ah perihal adanya seorang laki-laki Arab yang ingin kawin mut'ah, sebenarnya sang Biong mencoba berempati dan menempatkan diri pada posisi orang lain yang merupakan tindakan simbolis sehingga dapat menjelaskan keinginan atau maksud laki-laki Arab kepada perempuan yang mau dinikahi mut'ah. Pada proses ini telah terjadi pertukaran makna atau simbolsimbol signifikan melalui bahasa diantara laki-laki etnis Arab, perantara dan perempuan etnis Sunda yakni berencana melangsungkan perkawinan mut'ah. 


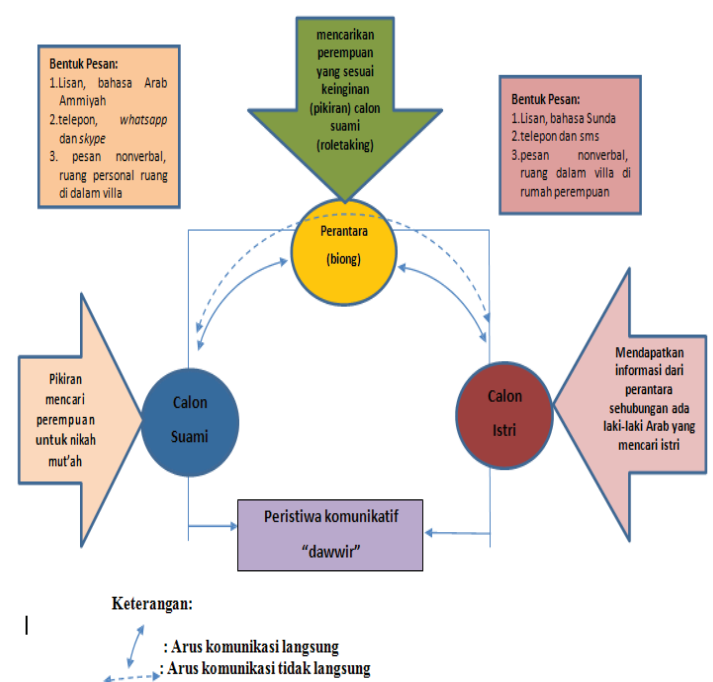

Gambar 1. Pola Komunikasi Calon Suami mut'ah dengan Perantara (Biong) dan Calon Istri mut'ah dengan Perantara (Biong) Ketika Dawwir.

Sumber: Hasil Observasi dan Wawancara, 2014

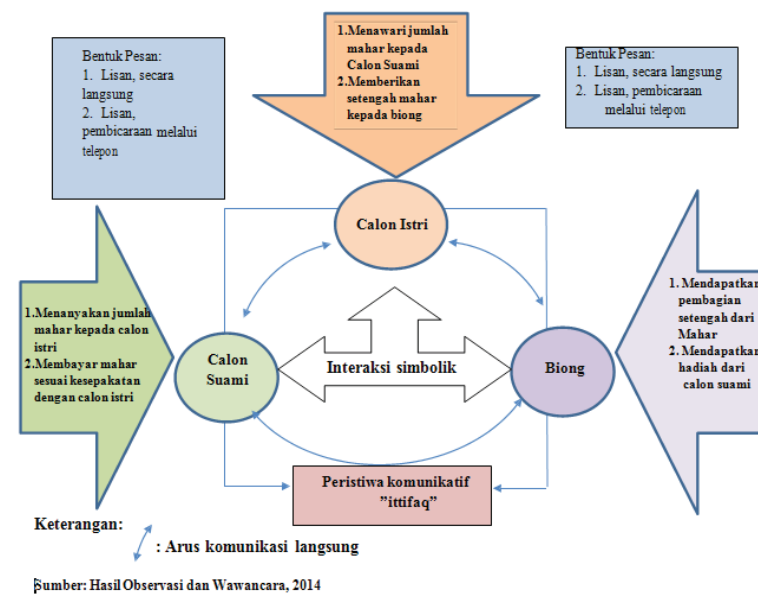

Gambar 2. Bagan Pola Komunikasi Calon Suami Calon Suami mut'ah dengan Perantara (Biong)

dan Calon Istri mut'ah dengan Perantara (Biong) dalam Peristiwa Komunikasi "Ittifaq"

Proses ittifaq mulai dapat dilihat pihakpihak yang terlibat dalam perilaku kawin mut"ah. Dalam interaksi simbolik, Mead mendefinisikan masyarakat (society) sebagai jejaring hubungan sosial yang diciptakan manusia. Individu-individu terlibat dalam masyarakat melalui perilaku yang mereka pilih secara sukarela. Jadi, masyarakat menggambarkan keterhubungan beberapa perangkat perilaku yang terus disesuaikan oleh individu-individu. Masyarakat ada sebelum individu tetapi juga diciptakan dan dibentuk oleh individu-individu dengan melakukan tindakan sejalan dengan orang lainnya (Forte dalam Turner, 2012: 107)

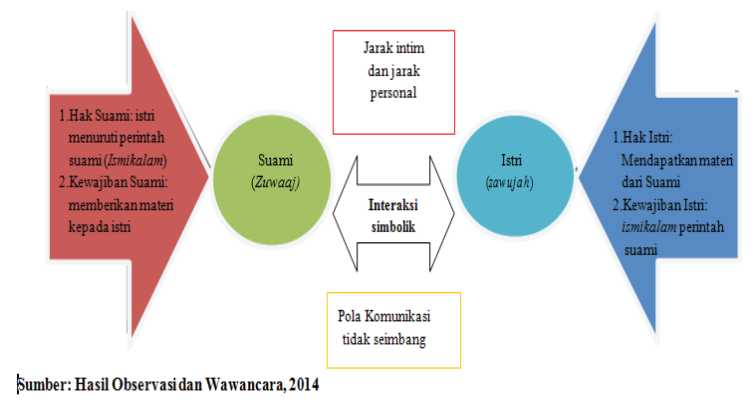

Gambar3. Bagan pola suami istri dalam Perkawinan mut ah ILaki-laki Etnis Arab dan Permpuan etnis Sunda di Cipanas Cianjur

Dalam Pola komunikasi suami istri menurut Joseph A Devito, salah satunya diantaranya yaitu Pola pemisah tidak seimbang. Dalam hubungan terpisah yang tidak seimbang, satu orang dalam keluarga (si suami atau si istri) mendominasi. Maka dari itu, satu orang ini secara teratur mengendalikan hubungan dan hampir tidak pernah meminta pendapat antara kedua belah pihak (si suami atau si istri). Sedangkan anggota keluarga (si suami atau si istri) yang dikendalikan membiarkannya untuk memenangkan argumentasi ataupun membuat keputusan. (Devito, 2007: 277-278).

Dalam perkawinan mut"ah yang terjadi di Cipanas Cianjur, suami mendominasi dalam pembuatan keputusan dan mengendalkan hubungan. Suami memiliki kekuatan luar biasa dalam mengendalikan hubungan. Sedangkan istri sebagai pihak yang dikendalikan membiarkannya membuat keputusan. Istilah ismi kalam menjelaskan bahwa suami memiliki kekuatan memberikan perintah sedangkan istri harus menuruti perintah suami tersebut. Jika dikaitkan dengan teori interaksi simbolik, maka orang akan bertindak sesuai dengan makna yang mereka miliki bersama, begitu juga istri mut"ah yang selalu menuruti perintah suaminya. Hal ini dilakukan karena itu dianggap baik oleh suaminya. Makna itu tercipta dari interaksi yang dilakukan oleh suami istri selama waktu perkawinan. Pada komunikasi suami istri, komunikasi yang terjadi adalah komunikasi kelompok primer. "Kelompok ini dapat dilihat dari karakteristik komunikasinya. Pertama kualitas komunikasi pada kelompok primer bersifat dalam dan meluas. Kedua komunikasi dalam kelompok primer bersifat personal. Ketiga, komunikasi lebih menekankan hubungan daripada isi" (Rahmat, 2008: 142-143). 
Komunikasi yang bersifat dalam artinya menembus kepribadian yang tersembunyi. Misalnya dalam tindak komunikatif merayu suami istri untuk meminta berhubungan suami istri. Komunikasi bersifat meluas artinya sedikit sekali kendala yang menentukan rentangan dan cara berkomunikasi. Pengungkapan hal-hal yang bersifat pribadi menggunakan lambang-lambang tertentu, akan dipahami oleh seorang istri jika suaminya sedang meminta berhubungan. Komunikasi bersifat personal, dimana hubungan suami istri mut"ah tidak bisa begitu saja dipindahkan kepada orang lain. Kata-kata, perilaku dan Pemberian hadiah sangat bersifat personal yang mungkin tidak diberitahukan kepada orang lain. Sedangkan komunikasi lebih menekan hubungan daripada isi maksudnya memelihara hubungan baik lebih penting dibandingkan dengan isi komunikasi. Misalnya ketika seorang istri tinggal di villa sedangkan suami membeli kebutuhan seharihari ke pasar atau ke supermarket menunjukkan adanya upaya untuk menjaga hubungan baik lebih penting daripada isi komunikasi. Bentuk penyampaian pesan lisan secara langsung berkaitan dengan zona proksemik yang dibangun oleh suami istri mut"ah, yaitu berada dalam jarak intim dan jarak personal. Oleh karena itu tidak banyak menggunakan handphone atau jaringan internet.

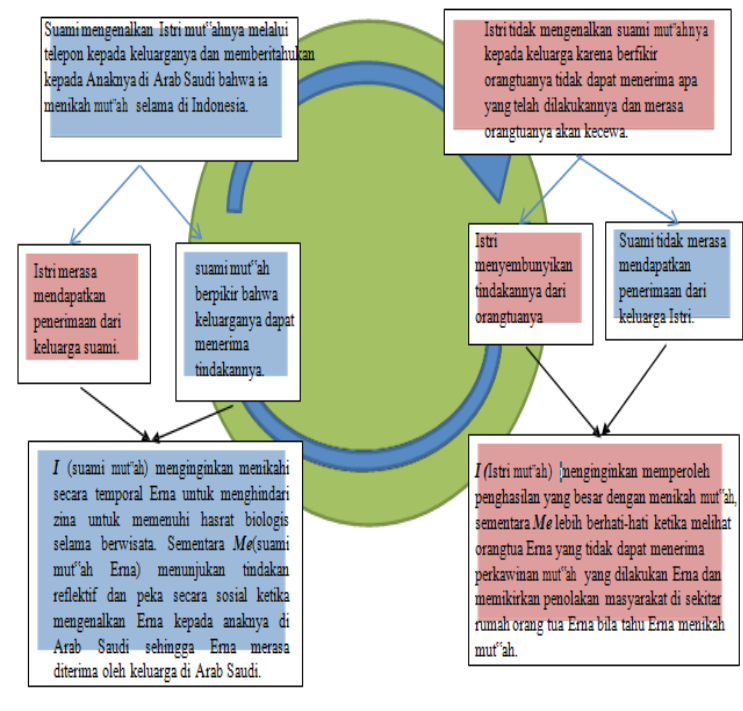

Sumber: Hasil wawancara dan observasi, 2014

Gambar 4. Bagan Pola Komunikasi Suami Istri Mut'ah dengan Keluarga Istri atau Keluarga Suami
Pola komunikasi yang akan dianalisa selanjutnya adalah pola komunikasi suami istri mut"ah dengan keluarga istri atau keluarga suami. Pada perkawinan yang dikenal dalam budaya Sunda dan budayaArab, keluargasangat berperan dalam pelaksanaan perkawinan. Bahkan, ketika perkawinan dilangsungkan, maka suami menjadi bagian dari keluarga istri. Sehingga ada sebutan minantu (menantu), mitoha (mertua), rayi beuteung (adik ipar), dahuan (kakak ipar).

Namun dalam perkawinan mut ${ }^{\text {ee }}$ ah di Cipanas Cianjur hubungan suami dengan keluarga istri tidak dibangun seperti dalam perkawinan yang lazim dilakukan di Cipanas yang memegang adat dan tradisi Sunda. Suami tidak mengenal keluarga istri secara dekat. Sebagian besar perkawinan mut ${ }^{\text {te }}$ ah justru tidak diketahui oleh keluarga perempuan. Suami dapat dikenalkan pada ayah atau ibu istri, tapi ayah dan ibu yang dikenalkan bukan ayah dan ibu yang sesungguhnya melainkan manipulasi yang sudah diatur oleh biong. Pak Ali menuturkan:

Engke teh dikenalkeun ieu bapana, ieu ibuna.(nanti dikenalkan ini ayahnya, ini ibunya) Padahal bukan. Tidak ada hubungan wali yang ada dengan cewe yang diakan dinikahi. Etamah disetting ku biong. Kadang orang Arabna oge teu apaleun. Etateh bapa palsu, ibu palsu. (itu diatur oleh biong. Kadang orang Arabnya tidak tahu bahwa itu ayah palsu, ibu palsu. (Wawancara dengan Pak Ali tanggal 10 maret 2014)

Sementara itu, hubungan istri dengan keluarga suami juga dapat terjadi ketika istri dikenalkan kepada anak suami melalui telepon. Seperti diungkapkan Erna yang pernah dikenalkan kepada putra suaminya di Arab Saudi: "saya dikenalkan dengan putranya., Sulton. Lalu saya berbincang dengan.Sulton menanyakan bagaimana sikap Ayahnya ke saya. Saya bilang ayahmu baik sekali sama saya dan begitu membahagiakan saya. "(Wawancara dengan Erna tanggal 21 April 2014)

Perkenalan dengan pihak keluarga Suami hanya sebatas menelepon dan tidak 
pernah bertemu secara langsung. Ketika waktu perkawinan habis, Erna tidak pernah lagi berhubungan baik dengan mantan suaminya maupun dengan keluarganya.

Keluarga, dalam teori interaksi simbolik adalah bagian dari masyarakat (society). Mead menyebutkan istilah partikular other yaitu: orang lain secara khusus yang merujuk pada individu-individu dalam masyarakat yang signifikan bagi kita. Orang-orang ini biasanya adalah anggota keluarga, teman dan kolega di tempat kerja serta supervisor. (Turner, 2012: 107). Keluarga adalah bagian penting yang memengaruhi pikiran dan diri. Erna tidak mengenalkan suami mute ahnya kepada keluarga karena berfikir mengenai pendapat orang tuanya apabila orang tuanya mengetahui perkawinan yang dijalani bersifat temporal. Erna merasa orang lain tidak dapat menerima apa yang telah dilakukannya dan merasa orangtuanya akan merasa kecewa. Erna mengatakan pada orangtuanya ia berprofesi sebagai SPG, dan mengatakan apa yang diberikan kepada orang tuanya seperti membangun rumah atau membeli sawah adalah hasil kerjanya sebagai SPG.

Apabila Erna menyembunyikan perkawinannya dari kelurganya sendiri, Erna justru dikenalkan melalui telepon kepada keluarga suaminya. Suami mut"ahnya secara terbuka memberitahukan kepada Anaknya di Arab Saudi bahwa ia menikahi Erna selama di Indonesia. Hal ini dilakukan suami muteah Erna karena berpikir bahwa keluarganya dapat menerima tindakannya. Ketika Erna berbicara melalui telepon, maka Erna mendapatkan penerimaan dari keluarga suami.

Dalam konsep interaksi simbolik, Mead mengatakan bahwa melalui bahasa orang mempunyai kemampuan untuk menjadi subjek dan objek bagi dirinya sendiri. Menurut Mead:

Sebagai subjek, kita bertindak dan sebagai objek kita mengamati diri kita sendiri bertindak. Mead menyebut subjek atau diri yang bertindak sebagai I dan objek atau diri yang mengamati adalah Me. I mungkin bersifat spontan, imflusif dan kreatif, sedangkan $\boldsymbol{M e}$ lebih reflektif dan peka secara sosial. (Turner, 2012: 107)
I(Erna) menginginkan memperoleh penghasilan yang besar dengan menikah muteah, sementara Me lebih berhati-hati ketika melihat orangtua Erna yang tidak dapat menerima perkawinan mut"ah yang dilakukan Erna dan memikirkan penolakan masyarakat di sekitar rumah orang tua Erna bila tahu Ernamenikah mut ${ }^{\text {ee }}$. Sedangkan I (suami mute ah Erna) menginginkan menikahi secara temporal Erna untuk menghindari zina untuk memenuhi hasrat biologis selama berwisata. Sementara $\boldsymbol{M e}$ (suami mut"ah Erna) menunjukan tindakan reflektif dan peka secara sosial ketika mengenalkan Erna kepada anaknya di Arab Saudi sehingga Erna merasa diterima oleh keluarga di Arab Saudi.

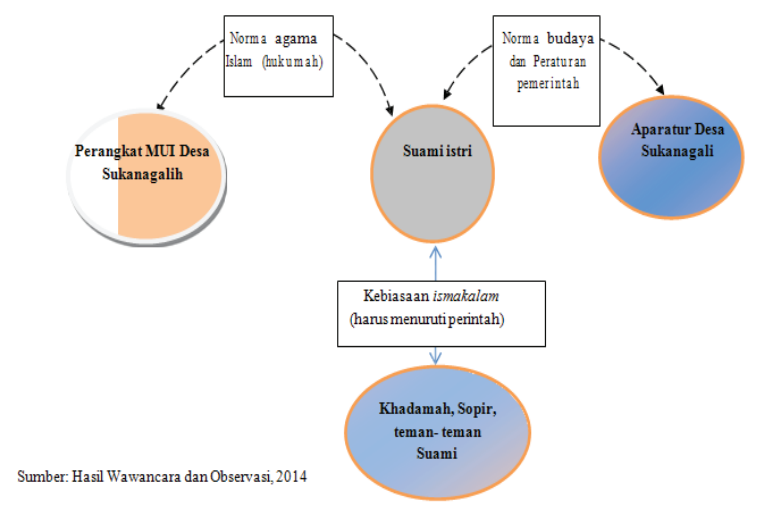

\section{Gambar 5. Pola Kominikasi Suami Istri Mut}

Masyarakat sekitar adalah orangorang yang berada disekitar villa kota bunga, yang oleh penulis diidentifikasikan menjadi: khadamah, sopir, teman-teman suami, aparatur desa, perangkat MUI dan masyarakat umum. Berdasarkan observasi yang telah Saya lakukan, ada interaksi dengan khaddamah, sopir dan teman-teman suami. Seorang khadamah (pembantu rumah tangga) adalah orang yang fasih berbahasa Arab dan dapat berinteraksi secara langsung dengan majikanannya. Suami dapat secara langsung berinteraksi dengan khadamah, begitu pun istri dapat langsung berinteraksi dengan khadamah. Perintah kepada khadamah biasanya meminta untuk memasakkan makanan, membersihkan dalam villa dan membawa pakaian kotor ke binatu (laundry). Sedangkan sopir bertugas mengantar suami ke tempat-tempat di luar villa.

Seorang khadamah (pembantu rumah tangga) adalah orang yang fasih berbahasa Arab dan dapat berinteraksi secara langsung dengan majikanannya. Suami dapat secara langsung 
berinteraksi dengan khadamah, begitu pun istri dapat langsung berinteraksi dengan khadamah. Perintah kepada khadamah biasanya meminta untuk memasakkan makanan, membersihkan dalam villa dan membawa pakaian kotor ke binatu (laundry).

Interaksi dengan perangkat desa dan MUI terjadi ketika adanya kunjungan dilakukan secara gabungan oleh aparatur desa dan MUI. Sedangkan tidak ada interaksi secara langsung dari suami istri kepada perangkat desa atau MUI. Begitu pula dengan masyarakat umum, tidak ada interaksi secara langsung antara suami istri dengan masyarakat umum. Bahkan, sumi istri mut ${ }^{\text {e }}$ ah cenderung bersembunyi dan merahasiakan perkawinannya, sehingga tidak diketahui oleh orang lain.

Masyarakat umum atau orang lain secara umum dalam konsep interaksi simbolik disebut generalized other. Menurut Mead, generalized other merujuk pada cara pandang dari sebuah kelompok sosial atau budaya sebagai suatu keseluruhan. Hal ini diberikan oleh masyarakat kepada kita, dan "sikap dari orang lain secara umum adalah sikap dari keseluruhan komunitas" (Mead dalam Turner, 2012: 108). Mead juga mengungkapkan:

Orang lain secara umum memberikan dan menyediakan informasi mengenai peranan, peraturan dan sikap yang dimiliki bersama oleh komunitas. Orang lain secara umumjuga memberikan kepada kita perasaan mengenai bagaimana orang lain bereaksi kepada kita dan harapan sosial secara umum. Perasaan ini berpengaruh dalam mengembangkan kesadaran sosial. Orang lain secara umum dapat membantu dalam menengahi konflik dimunculkan oleh kelompok-kelompok orang lain secara khusus yang berkonflik. (Turner, 2012: 108)

Interaksi antara suami istri yang menikah mut"ah dengan orang lain secara umum, dalam hal ini khadamah, sopir/guide, aparatur pemerintah dan perangkat MUI serta masyarakat lain tidak nampak secara eksplisit. Perkawinan muteah tersembunyi dari masyarakat secara umum. Namun, ketika ketua MUI melakukan kunjungan yang disebut "kontrol" dengan menggedor pintu villa menyiratkan adanya interaksi seperti yang diungkapkan Turner "orang lain secara umum memberikan dan menyediakan informasi mengenai peranan, peraturan dan sikap yang dimiliki bersama oleh komunitas". Penyebutan Jablay/JBL atau Onta dari masyarakat adalah wujud terjadinya interaksi yang tersirat dalam masyarakat di sekitar villa Kota Bunga.

\section{SIMPULAN}

Berdasarkan penjelasan yang telah diuraikan, maka disimpulkan pola komunikasi Etnis Arab dan Etnis Sunda dalam Perkawinan Mut'ah di Kecamatan Pacet Kabupaten Cianjur, antara lain: 1) Pola Komunikasi Calon Suami mut'ah dengan Perantara (Biong) dan Calon Istri mut'ah dengan Perantara (biong) Ketika Dawwir (mencari), Pola komunkasi Calon Suami mut'ah dengan Perantara (Biong) dan Calon Istri mut'ah dengan Perantara (biong) ketika ittifaq (menawar/kesepakatan).

2) Pola Komunikasi Suami Istri Mut'ah. 3) Pola Komunikasi Suami Istri mut'ah dengan keluarga istri atau keluarga suami. 4) Pola komunikasi suami istri mut'ah dengan masyarakat sekitar.

Situasi Komunikatif atau pesan nonverbal seperti pesan proksemik, pesan gestural, pesan fasial dan pesan artifaktual sangat dipengaruhi oleh aspek kebudayaan, khususnya budaya Arab. Peristiwa komunikatif yang terjadi dalam perkawinan mut'ah meliputi 4 (empat) peristiwa komunikatif, dimana dua peristiwa komunikatif dawwir dan ittifaq menjelaskan bagaimana proses human trafficking terjadi dalam perilaku perkawinan mut'ah: 1)Dawwir رود (mencari) dan 2) ittifaq قافـت (kesepakatan). Sedangkan dua peristiwa komunikatif berikutnya yakni zawaaj dan talaq menunjukkan lemahnya posisi perempuan dalam perkawinan mut'ah. 1) zawaaj (قاوز) (kawin) dan 2)Talaq (قَالَطلا) berarti melepaskan atau meninggalkan.

Tindak komunikatif terdiri dari:1)Tindak Komunikasi dalam cara memanggil atau menyebut seseorang dengan istilah tertentu. Seperti panggilan ya Gelbi..ya Habibi.., Babah, Banat, Madam, Onta dan JBL/ Jablay. 2)Tindak komunikasi dalam bentuk pernyataan, permohonan, perintah ataupun perilaku nonverbal, seperti merayu, bercanda, ekspresi marah, bercerita dan diskusi.

Komponen komunikasi yang membentuk Peristiwa Komunikasi dalam Perkawinan 
Mut'ah etnis Arab dengan etnis Sunda di Cipanas Cianjur, terdiri dari Setting: 1) Tempat, meliputi: Villa, Rumah Makan, Supermarket, Tempat Wisata; 2) Waktu, meliputi: bulan Rajab, Sya'ban\&Ramadan, disebut musim Arab. Waktu menjelang larut malam waktu terjainya peristiwa komunikatif; Partisipan: 1). Laki-laki orang Arab yang mencari istri untuk dinikahi secara mut'ah. 2) Perantara (biong) yang mencarikan Komu-nikasi antara Orang Arab dengan perempuan yang mau dinikahi mut'ah. 3) Perempuan etnis Sunda yang kawin mut'ah dengan Laki-laki orang Arab. 4). Pihak keluarga perempuan yang kawin mut'ah dengan Laki-laki Arab. 5) masyarakat sekitar Villa Kota Bunga. Bahasa Tabu: 1) Tunggu sebentar (intidar); 2)Tidak mau (la ma abgoh); 3)Pembicaraan mengenai masa lalu pasangan. Bentuk dan Isi Pesan: 1) lisan secara langsung, menggunakan bahasa Arab Amiyah; 2) Menggunakan gadget (handphone); 3)Pesan tulisan. Norma: 1) Norma Agama berdasarkan Ajaran Agama Islam; 2) Norma Budaya Arab dan Budaya Sunda. Kebiasaan :1) Calon Suami menanyakan virgin atau pernah menikah; 2)Mahar ditentukan oleh permintaan calon istri;3) Waktu perkawinan ditentikan oleh calon suami; 4) Lokasi perkawinan di kediaman laki-laki (villa). Norma interpretasi: 1) Perilaku menyimpang dari Norma Agama dan Norma Budaya; 2) Lemahnya posisi perempuan; alasan ekonomi\&human trafficking Genre: Perbedaan Panggilan atau penyebutan Babah, Onta, Madam, Banat dan Jablay; 2) Berbicara dengan mengulang katakata untuk penegasan makna yang diharapkan dari percakapan. Komponen yang dominan membentuk peristiwa komunikasi dalam perkawinan mut'ah adalah setting, bentuk dan isi pesan, norma, interpretasi norma, kebiasaan dan genre. Sedangkan komponen yang tidak dominan yaitu urutan tindakan dan Ends atau tujuan mengenai peristiwa secara umum. Hal ini dikarenakan urutan tindakan dianggap statis dan tujuan mengenai peristiwa secara umum pun tidak berubah.

Saran Akademis yang penulis berikan berdasarkan hasil dari penelitian ini diantaranya: (1) Penelitian ini diharapkan memacu adanya penelitian lanjutan sehubungan dengan berkembangnya sektor bisnis orang Arab di Cipanas Cianjur yang dikelola oleh masyarakat setempat. Maka penelitian dapat mengkaji mengenai komunikasi bisnis orang Arab di Cipanas Cianjur, (2) Penelitian lanjutan juga dapat meneliti mengenai fenomena Tenaga Kerja Wanita yang dulunya bekerja di Arab saudi sekarang bekerja sebagai khadamah (pembantu) di Kota Bunga Cipanas Cianjur dengan menggunakan pendekatan tradisi fenomenologi, (3) Perlunya Penelitian kuanti-tatif atau survey mengenai penelusuran jumlah orang Arab yang berkunjung ke Kota Bunga. Penelusuran dapat dilakukan dengan mendata jumlah wisatawan yang berkunjung ke villa kota Bunga, (4) Penelitian lanjutan dapat meneliti keberadaan biong atau perantara yang menghubungkan orang Arab dengan orang Sunda dengan menggunakan pendekatan tradisi fenomenologi, dan (5) Penelitian lanjutan dapat dilakukan dengan meneliti kasus human trafficking atau kasus ketidakadilan gender di mana terdapat diskriminasi posisi perempuan di Kota Bunga Cipanas dengan pendekatan studi kasus.

Sedangkan untuk saran praktis, peneliti memberikan saran antara lain: (1) Perlu adanya upaya membuat paguyuban-paguyuban berbagai profesi yang ada dan berhubungan dengan keberadaan orang Arab di Cipanas. Upaya ini diharapkan dapat diapresiasi dan didukung oleh instansi terkait, (2) Pemerintah Daerah dapat membuat anggaran yang memadai untuk memberikan kesempatan kepada mantan Jbl/jablay perempuan yang pernah menikah mut'ah. Sehingga mendapatkan pekerjaan lain yang lebih baik dengan membuat pelatihan keterampilan yang bermanfaat atau membangun rumah-rumah transisi sebelum para mantan Jbl/perempuan yang pernah menikah kontrak kembali kepada keluarganya, (3) Adanya dominasi budaya Arab di Cipanas Cianjur, khususnya di daerah Kota Bunga memprihatinkan karena menggeser budaya Sunda yang merupakan budaya yang dipegang teguh oleh masyarakat di Cipanas. Oleh karena itu, dengan adanya penelitian ini perlu diambil langkah baik oleh budayawan Sunda atau masyarakat setempat untuk mempertahankan budaya asli yang menjadi identitas masyarakat setempat sejak dulu. Pengenalan budaya Sunda kepada orang Arab dengan menggunakan saluran komunikasi yang beragam dan menarik, dan (4) Penelitian ini diharapkan menjadi 
gambaran terkini bagi instansi terkait untuk mengetahui lebih dalam kondisi real interaksi orang Arab dengan masyarakat setempat, sehingga dapat dibuat kebijakan yang tepat dalam mengantisipasi dan menanggulangi human trafficking khususnya di Cipanas Cianjur.

\section{DAFTAR PUSTAKA}

Al Jawi, M. S. (2013). Kawin kontrrak menurut hukum islam. Diakses dari https://hizbut-tahrir.or.id/2013/05/11/ kawin-kontrak-menurut-hukum-islam/

DeVito, J. A. (2007). The interpersonal communication book. edisi 11. Pearson Educations,Inc Geertz, Clifford."Thick Description: Toward an Interpretive
Theory of Culture". In The Interpretation of Cultures: Selected Essays. New York: Basic Books, 1973. 3-30.

Koeswarno, E. (2008). Metode penelitian kualitatif: etnografi komunikasi. Bandung: Widya Padjadjaran.

Mulyana, D. (2008). Metodologi Penelitian Kualitatif: Paradigma Baru Ilmu Komunikasi dan ilmu sosial lainnya. Bandung: Remaja Rosdakarya

Rahmat, J. (2008). Psikologi komunikasi. Bandung: Remaja Rosdakarya

Turner, R. W. (2012). Pengantar Teori Komunikasi Analisis dan Aplikasi. Introducing Communication Theory: Analysis and Application. Jakarta: Salemba Humanika. 